\title{
On the origin of the increased tissue iron content in graded magnesium deficiency states in the rat
}

\author{
BY KLAUS SCHUMANN ${ }^{1}$, ANNETTE LEBEAU ${ }^{2}$, URSULA GRESSER ${ }^{3}$, THEODOR \\ GUNTHER $^{4}$ AND JÜRGEN VORMANN ${ }^{4}$ \\ ${ }^{1}$ Walther Straub-Institut für Pharmakologie u. Toxikologie, Nussbaumstr. 26, D-80336 München, Germany \\ ${ }^{2}$ Pathologisches Institut, Thalkirchnerstr. 36, 80337 München, Germany \\ ${ }^{3}$ Medizinische Poliklinik, Pettenkoferstr. 8a, 80336 München, Germany \\ ${ }^{4}$ Institut für Molekularbiologie und Biochemie, Arnimstr. 22, 14195, Berlin, Germany
}

(Received 4 March 1996 - Revised 24 May 1996 - Accepted 11 June 1996)

\begin{abstract}
To investigate the mechanism of tissue Fe accumulation in graded $\mathrm{Mg}$ deficiency rats were fed on diets of different $\mathrm{Mg}$ contents $(70,110,208,330$, and $850 \mathrm{mg} \mathrm{Mg} / \mathrm{kg}$ ) for 10,20 , and $30 \mathrm{~d}$ during rapid growth. There was no significant impact of $\mathrm{Mg}$ deficiency or high luminal $\mathrm{Mg}$ concentrations on intestinal ${ }^{59} \mathrm{Fe}$ transfer in vitro or in vivo. Plasma $\mathrm{Mg}$ concentrations and body weight started to decrease after $10 \mathrm{~d}$. Significant haemolytic anaemia was observed after $20 \mathrm{~d}$ with siderosis in liver and spleen developing in parallel. Anaemia showed no features of Fe deficiency or inflammation. Comparison between the $70 \mathrm{mg} \mathrm{Mg} / \mathrm{kg}$ group and animals that received the same quantity of a $\mathrm{Mg}$. adequate diet $(850 \mathrm{mg} \mathrm{Mg} / \mathrm{kg}$ ) permitted estimation of quantities of Fe liberated by haemolysis and the increased Fe content in liver and spleen. Both variables showed a high degree of correlation, indicating that the excess of liberated haemoglobin Fe was stored in the tissue. The erythropoietic activity was high during rapid growth, i.e. at days 10 and 20 and decreased significantly after $30 \mathrm{~d}$ in all except the most $\mathrm{Mg}$-deficient groups. However, haemolytic anaemia developed because even the high erythropoietic activity in the 70 and $110 \mathrm{mg} \mathrm{Mg} / \mathrm{kg}$ groups was not sufficient to recycle all haemoglobin Fe liberated by haemolysis. After $30 \mathrm{~d}$ of $\mathrm{Mg}$-deficient feeding the erythrocyte $\mathrm{Mg}$ content had decreased to $40 \%$ of control values. According to the literature Mg-deficient erythrocytes have a decreased survival time which is likely to be the cause of the observed haemolysis.
\end{abstract}

Magnesium: Haemolysis: Iron: Haemosiderosis

Increased stress susceptibility, histamine reactions, growth reduction and the pathophysiological consequences of a disturbed $\mathrm{Ca}$ metabolism are among the sequels of severe $\mathrm{Mg}$ deficiency in rats (Günther, 1981). On the other hand, pharmacological $\mathrm{Mg}$ doses are applied for suppression of uterine contractility, treatment of pre-eclampsia and certain types of cardiac arrhythmia (Classen et al. 1994). The use in the treatment of myocardial infarction is under discussion (Woods \& Fletcher, 1994). The cellular Mg content is tightly regulated. With the exception of erythrocytes it changes only slightly even when the extracellular $\mathrm{Mg}$ concentration is drastically decreased (Vormann et al. 1995). Thus, intracellular effects of $\mathrm{Mg}$ deficiency must be mediated indirectly, e.g. by modulation of the cellular Ca content or of catecholamine effects (Günther, 1981). An intracellular mediator is also needed to explain increased hepatic lipid peroxidation in severely $\mathbf{M g}$-deficient rats. This phenomenon is accompanied by hepatic siderosis and a decreased hepatic vitamin $\mathrm{E}$ 
content (Günther et al. 1992). In rats in different states of $\mathrm{Mg}$ deficiency the extent of malondialdehyde production was positively correlated to the Fe content in a variety of tissues (Vormann et al. 1995).

As Fe is known to catalyse lipid peroxidation by Fenton chemistry (Crichton, 1991) these findings argue that the stimulation of lipid peroxidation in $\mathrm{Mg}$ deficiency is the consequence of increased tissue Fe accumulation. Therefore, the present study focused on the mechanism by which the intracellular Fe content may be modulated in $\mathrm{Mg}$ deficiency. It investigated whether there is increased intestinal Fe absorption or an inhibitory effect of high luminal $\mathrm{Mg}$ concentrations on Fe absorption which, consequently, would be reduced in $\mathrm{Mg}$ deficiency. In addition, the time course and extent of haemolysis and increased erythropoiesis were compared with the time course and extent of tissue Fe accumulation at different degrees of $\mathrm{Mg}$ deficiency in order to investigate whether there is a shift of haem $\mathrm{Fe}$ into the tissue. Histology was used to determine the location of accumulated Fe in the tissue, the extent of medullar and extramedullar erythropoiesis and the extent of morphological damage. Some of the data were first presented at the spring meeting of the Deutsche Gesellschaft für experimentelle und klinische Pharmakologie und Toxikologie in March 1994.

\section{MATERIALS AND METHODS}

\section{Animals and experimental design}

The experiments were performed according to the rules of animal care and were approved by the local animal protection committee (Tierschutzkommission der Regierung von Oberbayern: AZ 211 - 2531 - 25/93).

Expt 1. Ninety-six conventionally bred male Wistar rats (Interfauna, Tuttlingen, Germany) were housed in stainless-steel cages, five animals per cage unless stated otherwise ( $12 \mathrm{~h}$ light-12 $\mathrm{h}$ dark, $22^{\circ}, 60 \%$ humidity). The animals were randomly divided into six groups of fifteen animals each. In five groups the rats received, ad libitum, diets with different $\mathrm{Mg}$ content. In the sixth group the animals were fed on a $\mathrm{Mg}$-adequate diet ( $850 \mathrm{mg} \mathrm{Mg} / \mathrm{kg}$ ) and were allocated the average amount of food that had been consumed by the most $\mathrm{Mg}$-deficient group ( $70 \mathrm{mg} \mathrm{Mg} / \mathrm{kg}$ ) on the day before (parallel feeding). The animals in the parallel-feeding group were housed individually to avoid competition for the restricted food allocation. Food consumption was measured daily. Spillage was accounted for by feeding the animals over a big steel plate from which the spilled material was collected and quantified. Food consumption was significantly reduced in the $70 \mathrm{mg} \mathrm{Mg} / \mathrm{kg}$ group after 20 and $30 \mathrm{~d}$ compared with $850 \mathrm{mg} \mathrm{Mg} / \mathrm{kg}$ ad libitum feeding. The reduction amounted to $20-25 \%$ of ad libitum intake (Table 1). The food was allocated to the restrictively-fed animals once daily in the mornings. The animals consumed only part of their allocation immediately which showed that they were not in a situation of severe starvation. The animals in the $70 \mathrm{mg} \mathrm{Mg} / \mathrm{kg}$ group were numbered individually in order to relate their results to those of the corresponding animal in the $850 \mathrm{mg} \mathrm{Mg} / \mathrm{kg}$ parallelfeeding group with the matching weight at the beginning of the experiment.

Body weights on the day of arrival and at the beginning of the feeding experiment are given in Table 2 . There were no significant differences between the animals allocated to the different feeding groups at either of these points in time. Diets for the experiments were prepared by adding $\mathrm{MgCl}_{2}$ to a basal Mg-deficient diet (Ssniff, Soest, Germany; for composition see Table 3) leading to $\mathrm{Mg}$ contents of $70,110,208,330$ and $850 \mathrm{mg} \mathrm{Mg} / \mathrm{kg}$. 
Table 1. Food consumption ( $\mathrm{g} / \mathrm{d}$ per animal) of rats receiving diets containing 70 or $850 \mathrm{mg}$ magnesium $/ \mathrm{kg}$ during growth

(Mean values and standard deviations)

\begin{tabular}{lrlllr}
\hline Diet... & & \multicolumn{2}{c}{$70 \mathrm{mg} \mathrm{Mg} / \mathrm{kg}$} & & \multicolumn{2}{c}{$850 \mathrm{mg} \mathrm{Mg} / \mathrm{kg}$ ad libitum } \\
\cline { 5 - 6 } & $n$ & Mean & SD & Mean & SD \\
\hline Acclimatization period (7 d) & 15 & 23.1 & 2.6 & 22.8 & 2.0 \\
Days 0-10 & 5 & 23.4 & 2.7 & 25.3 & 1.9 \\
Days 10-20 & 5 & 20.8 & 1.7 & $26.9 *$ & 1.3 \\
Days 20-30 & 5 & 21.0 & 2.0 & $26.1^{*}$ & 1.4 \\
\hline
\end{tabular}

*Mean values were significantly different from those for the $70 \mathrm{mg} / \mathrm{kg}$ group, $P<0.05$ (Student's $t$ test).

The $\mathrm{Mg}$ content of the diets was assessed by atomic absorption spectrophotometry in ashed portions. The Fe content in all diets was $180 \mathrm{mg} / \mathrm{kg}$. During an acclimatization period of $7 \mathrm{~d}$ after arrival the animals were fed on the control diet $(850 \mathrm{mg} \mathrm{Mg} / \mathrm{kg})$. All animals had free access to distilled water. After 10, 20, and $30 \mathrm{~d}$ five rats of each feeding group were killed. Six additional rats (three animals/cage) served to provide initial day 0 values for the variables measured. All animals were fasted overnight before slaughter. All animals including the six rats on day 0 were killed by bleeding, under ether anaesthesia.

In all animals of Expt 1 the number of erythrocytes, haemoglobin concentration, packed cell volume, mean corpuscular volume, mean corpuscular haemoglobin, erythrocyte distribution width and the number of reticulocytes, the plasma concentrations of lactate dehydrogenase ( $E C$ 1.1.1.2; $\mathrm{LDH}$ ), bilirubin, transferrin, Fe and $\mathrm{Mg}$ as well as the Fe content in liver and spleen were determined, as well as the erythrocyte $\mathrm{Mg}$ content and the plasma concentrations of urea and creatinine after $30 \mathrm{~d}$. Liver, spleen, kidney and bone marrow were examined histologically after $30 \mathrm{~d}$.

Expt 2. Intestinal Fe absorption was determined in thirteen severely $\mathrm{Mg}$-deficient male Wistar rats (Mg-deficient diet, Ssniff; $70 \mathrm{mg} \mathrm{Mg} / \mathrm{kg}$ ) and in twenty-three $\mathrm{Mg}$-adequate controls (Ssniff; $850 \mathrm{mg} \mathrm{Mg} / \mathrm{kg}$ ). Except for the $\mathrm{Mg}$ content both diets had the same nutrient and mineral composition (Table 3). The animals were housed in stainless steel cages as described in Expt 1 and received food and water ad libitum. After $30 \mathrm{~d}$ the body weights of the animals on the $70 \mathrm{mg} \mathrm{Mg} / \mathrm{kg}$ diet had increased from 193 (SD 8) $\mathrm{g}$ to 346 (SD 18) g; corresponding values for the $850 \mathrm{mg} \mathrm{Mg} / \mathrm{kg}$ group were 190 (SD 12) $\mathrm{g}$ and 462 (SD 26) g. Proximal small intestines were removed under ether anaesthesia to determine the ${ }^{59}$ Fe-transfer in vitro.

\section{Determination of duodenal ${ }^{59} \mathrm{Fe}$ transfer in vitro}

One segment of proximal small intestine (approximately $100 \mathrm{~mm}$ length, beginning $10 \mathrm{~mm}$ distal of the pylorus) was removed from each animal under ether anaesthesia and perfused in vitro according to the method of Fisher \& Parsons (1949). The method, as modified by ourselves, has been used repeatedly to determine intestinal ${ }^{59} \mathrm{Fe}$ transfer and has been extensively described elsewhere (Schümann et al. 1986, 1990a,b). Conditions of in vitro incubation were: perfusion with bicarbonate-buffered Tyrode solution; $37^{\circ}, \mathrm{pH} 7.2$; hydrostatic perfusion pressure: $25 \mathrm{~cm} \mathrm{H}_{2} \mathrm{O}$; flow rate: $50 \mathrm{ml} / \mathrm{min}$, incubation time: $2 \mathrm{~h}$. During perfusion the active transfer of glucose against a concentration gradient of $>1: 2$ 


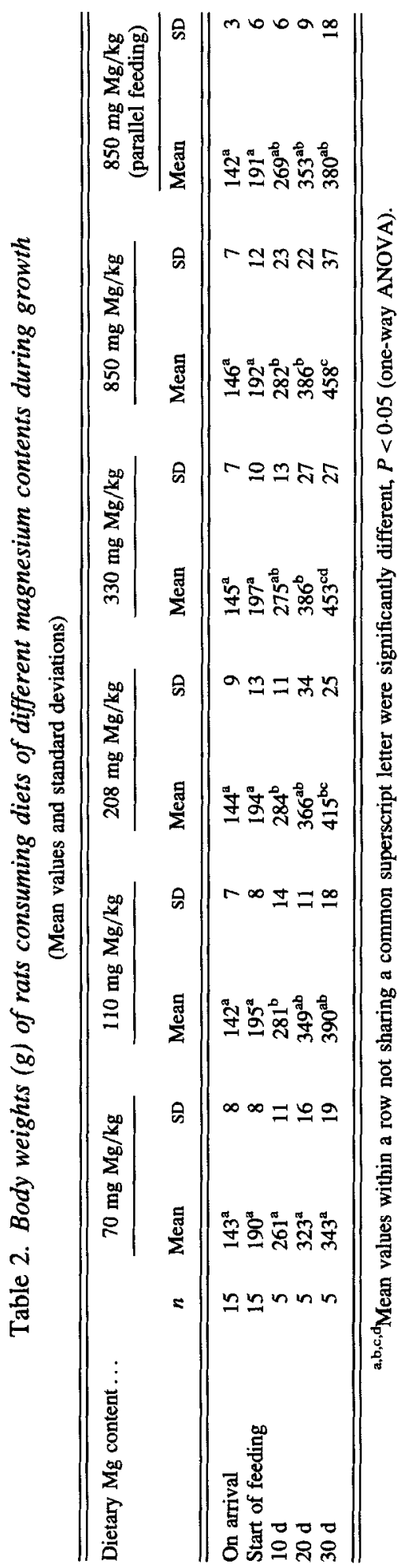


Table 3. Composition of the basal magnesium-deficient diet*

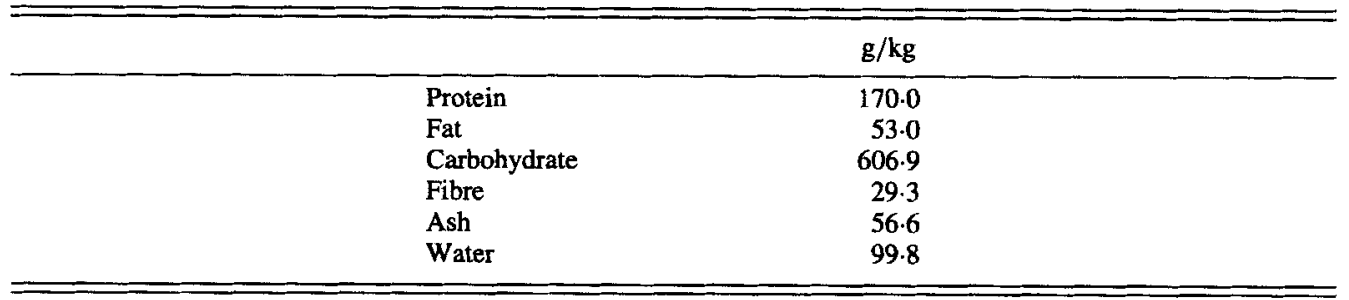

*The diet also contained the following; vitamins $(\mathrm{mg} / \mathrm{kg}$ ): retinyl acetate $5 \cdot 16$, cholecalciferol, $0.013, \alpha$-tocopherol 164.0 , menadione $10 \cdot 0$, thiamin 20.0 , riboflavin $20 \cdot 3$, pyridoxine $15 \cdot 0$, cyanocobalamin 0.04 , nicotinic acid $50 \cdot 0$, pantothenic acid 50.0, pteroylmonoglutamic acid 10.0, biotin 0.2 , choline 1010 , para-aminobenzoic acid 100.0 , inositol 111.0, ascorbic acid 20.0; minerals (g/kg): Ca 9.50, P 7.50, $\mathrm{Mg} \mathrm{0.07,} \mathrm{Na} \mathrm{2.50,} \mathrm{K} \mathrm{7.00,} \mathrm{S} \mathrm{2.81,} \mathrm{Cl} \mathrm{3.66;}$ trace elements (mg/kg): Fe 182.1, Mn 100.8, $\mathrm{Zn} \mathrm{30.4,} \mathrm{Cu} \mathrm{12 \cdot 2,} \mathrm{I} \mathrm{0.45,} \mathrm{Mo} \mathrm{0.20,} \mathrm{F} \mathrm{4.19,} \mathrm{Se} \mathrm{0.31.}$

was continuously monitored and served as vitality criterion. The cumulative water transfer was determined gravimetrically and was close to linear during the entire experimental period. Transfer of glucose and water showed no significant differences between $\mathrm{Mg}$ deficient and control segments.

Fe was labelled with ${ }^{59} \mathrm{FeCl}_{3}(7.4 \mathrm{kBq} / \mathrm{ml})$ and offered at luminal concentrations of 10 and $100 \mu \mathrm{mol} \mathrm{Fe} / 1$. It was chelated with a twofold molar excess of nitrilotriacetic acid to prevent formation of iron hydroxide. ${ }^{59} \mathrm{Fe}$ radioactivity was determined in a gammacounter (Contron GAMMAmatic, Contron, Eching, Germany). Intestinal Fe transfer rates were calculated from the ratio between the ${ }^{59} \mathrm{Fe}$ activity in the absorbate and in the perfusate. After an initial lag phase the cumulative ${ }^{59} \mathrm{Fe}$ transfer was linear in all experimental groups. The length of the segments was measured while segments were suspended under a uniform tension of a $6 \mathrm{~g}$ weight. To test the impact of excess $\mathrm{Mg}$ on intestinal ${ }^{59} \mathrm{Fe}$ transfer $10 \mathrm{mmol} \mathrm{Mg} / 1\left(\right.$ as $\left.\mathrm{MgCl}_{2}\right)$ was added to the perfusate at luminal $\mathrm{Fe}$ concentrations of $10 \mu \mathrm{mol} / 1$ and $100 \mu \mathrm{mol} / 1$. The perfusate in control experiments contained $50 \mu \mathrm{mol} \mathrm{Mg} / 1$.

\section{Determination of intestinal ${ }^{59} \mathrm{Fe}$-transfer in vivo}

Proximal jejunal segments from $\mathrm{Mg}$-deficient rats (diet: $70 \mathrm{mg} \mathrm{Mg} / \mathrm{kg}, 30 \mathrm{~d}$ ) as well as from three $\mathrm{Mg}$-adequate animals (diet: $850 \mathrm{mg} / \mathrm{kg}, 30 \mathrm{~d}$ ) were used to cross-check the in vitro ${ }^{59} \mathrm{Fe}$ transfer data. For this purpose the animals were anaesthetized (Ketanest: $0.5 \mathrm{mg} / \mathrm{kg}$ ) and the ligated segment (approximately $100 \mathrm{~mm}$ length, starting at the flexura duodenal-jejunalis) was filled with ${ }^{59} \mathrm{FeSO}_{4}$ solution $(0.5 \mathrm{ml}, 20 \mathrm{mmol} / 1$ ascorbate, $5 \mathrm{mmol}$ glucose/ 1 in physiological saline, $\left.\mathrm{pH} 2,1 \mathrm{mmol} \mathrm{Fe} / 1,0.185 \mathrm{MBq}^{59} \mathrm{Fe} / \mathrm{ml}\right)$. The ${ }^{59} \mathrm{Fe}$ radioactivity in the animal was determined in triplicate in a whole-body counter for small animals (ARMAC Model 446, Packard Instruments, Palo Alto, CA, USA). After $30 \mathrm{~min}$ the ligated segments were removed from the animal and the ${ }^{59} \mathrm{Fe}$ radioactivity was determined in the carcass. The retained ${ }^{59} \mathrm{Fe}$ activity was related to the length of the ligated segments and to the duration of the experiment. Results were expressed as transfer rates (pmol/cm per min), assuming the same specific activities in the carcass and in the luminal solution.

\section{Determination of haematological and plasma variables; tissue metal content}

Heparinized blood was obtained by puncturing the abdominal aorta. Some of the blood was centrifuged $\left(4^{\circ}, 500 \mathrm{~g}\right.$ ). Plasma was frozen at $-20^{\circ}$ to determine $\mathrm{Mg}, \mathrm{Ca}, \mathrm{Zn}$, and $\mathrm{Fe}$ 
concentrations by atomic absorption spectrometry (Philips SP9, Philips, Kassel, Germany). Packed cell volume, haemoglobin concentration and the number of erythrocytes were determined by use of a Coulter counter. The plasma concentration of LDH was determined photometrically by use of the pyruvate method. Total bilirubin was determined after reaction with 2,5 dichlorophenyl diazonium (DPA method). This compound binds quantitatively to bilirubin to give azobilirubin which was determined photometrically. Urea and creatinine were quantified by use of the urease (EC 3.5.1.5) and pikrat (Jaffe) method according to the manual of the manufacturer (Boehringer, Mannheim, Germany: BM/Hitachi 717 System; wavelength: bilirubin 660-570 nm; LDH $405-340 \mathrm{~nm}$; urease 405-340 nm; creatinine 570-505 nm). Reticulocytes were counted in blood smears stained with Brilliant Cresyl Blue.

Liver, kidney, spleen, and the femur were removed. The wet weight of liver, spleen, and kidney after $30 \mathrm{~d}$ did not differ significantly between the $70 \mathrm{mg} \mathrm{Mg} / \mathrm{kg}$ group and the $850 \mathrm{mg} \mathrm{Mg} / \mathrm{kg}$ ad libitum group ( $P>0.05$, Student's $t$ test). The tissues were washed in $250 \mathrm{mM}$-sucrose, freeze-dried and dry weight was determined. The powdered tissues were ashed in a plasma processor (Model $200 \mathrm{E}$, Technics, München, Germany), dissolved in $0.1 \mathrm{M}-\mathrm{HCl}$ and the tissue Fe content was determined in liver and spleen, after appropriate dilution, by use of atomic absorption spectrometry (Philips SP9, Philips). All reagents used were of analytical grade and purchased from Merck, Darmstadt, Germany and Sigma, München, Germany; ${ }^{59} \mathrm{Fe}$ was supplied by NEN Dreieich, Germany.

\section{Histological examination}

For light-microscopic evaluation of liver, spleen and kidney small specimens from all animals after a $30 \mathrm{~d}$ feeding period were fixed in a $40 \mathrm{ml} / 1$ neutral buffered formalin, while bone marrow specimens were fixed and carefully decalcified according to the method of Schaefer (1995). Paraffin sections $(4 \mu \mathrm{m})$ were stained with haemotoxylin and eosin, periodic acid-Schiff (PAS) reagent and trichrome. Perls' blue reaction was used for histochemical determination of Fe storage. Calcification in the kidneys was demonstrated by Kossa's stain. Fe storage in the macrophages from the spleen and in Kupffer cells from the liver was semiquantitatively evaluated, as well as erythropoiesis in the bone marrow and extramedullary erythropoiesis in the spleen. These variables were ranked on a scale from $\emptyset$ to +++ according to the grading system proposed by Searle et al. (1994). This system is based on the ease of observation and the magnification required for lightmicroscopical examination.

\section{Statistical treatment of data}

Significant differences between the mean values of the different groups were analysed by one-way ANOVA (5\% level). The homogeneity of variances was checked for each ANOVA by means of Hartley's test. When significant differences were found, the Scheffé test was used ( $5 \%$ level) to test which means were significantly different from each other and which formed a homogeneous group. Differences between the transfer variables, in food consumption, and organ weight as well as between urea and creatinine concentrations in the most $\mathrm{Mg}$-deficient and Mg-adequate groups were assessed by means of Student's $t$ test $(P<0.05)$. 


\section{RESULTS}

\section{Graded magnesium deficiency}

The plasma $\mathrm{Mg}$ concentration was significantly reduced in all groups with less than $850 \mathrm{mg} \mathrm{Mg} / \mathrm{kg}$ in the diet after 10, 20 and $30 \mathrm{~d}$ (see Table 7). After 10 and $20 \mathrm{~d}$ body weight increases were significantly lower in the $70 \mathrm{mg} \mathrm{Mg} / \mathrm{kg}$ group compared with the $850 \mathrm{mg} \mathrm{Mg} / \mathrm{kg}$ group. After $30 \mathrm{~d}$ body weight was significantly decreased in all groups with less than $208 \mathrm{mg} \mathrm{Mg} / \mathrm{kg}$. At this point in time the body weight in the $70 \mathrm{mg} \mathrm{Mg} / \mathrm{kg}$ group was also significantly lower than that of the animals fed on a $\mathrm{Mg}$-adequate diet in parallel, indicating that weight reduction in $\mathrm{Mg}$-deficiency was not exclusively due to a reduced food intake (Table 2). Both variables indicated that the chosen feeding scheme led to different degrees of $\mathrm{Mg}$-deficiency as intended.

\section{Intestinal ${ }^{59} \mathrm{Fe}$ transfer (Expt 2)}

There were no significant differences between the ${ }^{59} \mathrm{Fe}$ transfer rates in vitro in severely $\mathrm{Mg}$-deficient and $\mathrm{Mg}$-adequate duodenal segments, either at a luminal ${ }^{59} \mathrm{Fe}$ concentration of 10 or of $100 \mu \mathrm{mol} / \mathrm{l}$ (Table 4). Addition of $\mathrm{MgCl}_{2}(10 \mathrm{mmol} / \mathrm{l})$ to the luminal perfusion medium had no impact on ${ }^{59} \mathrm{Fe}$ transfer rates. The jejunal ${ }^{59} \mathrm{Fe}$ transfer data in vivo support these findings (Table 4).

\section{Haematological findings, tissue iron accumulation and clinical chemistry (Expt 1)}

Significant reductions in erythrocytes, haemoglobin concentration, and packed cell volume were observed no earlier than after $30 \mathrm{~d}$ (Table 5) when the haematological variables indicative for anaemia were reduced by approximately $10-20 \%$ in the $70 \mathrm{mg} \mathrm{Mg} / \mathrm{kg}$ group compared with those animals with the same intake of $\mathrm{Mg}$-adequate food $(850 \mathrm{mg} \mathrm{Mg} / \mathrm{kg})$. Anaemia in $\mathrm{Mg}$ deficiency was neither microcytic nor hypochromic (Table 5). Erythrocyte distribution width was significantly increased in the $70 \mathrm{mg} \mathrm{Mg} / \mathrm{kg}$ group after $30 \mathrm{~d}$. Plasma transferrin concentrations were not significantly reduced in severe $\mathrm{Mg}$ deficiency (plasma transferrin concentrations after $30 \mathrm{~d}: 70 \mathrm{mg} \mathrm{Mg} / \mathrm{kg} 2800$ (SD 300) $\mathrm{mg} / \mathrm{l} ; 850 \mathrm{mg} \mathrm{Mg} / \mathrm{kg}$ ad libitum 3000 (SD 300) $\mathrm{mg} / \mathrm{l}$; other results not shown). Plasma Fe was significantly increased in the $70 \mathrm{mg} \mathrm{Mg} / \mathrm{kg}$ group after 20 and $30 \mathrm{~d}$. Significant decreases in plasma Fe were seen in the $850 \mathrm{mg} \mathrm{Mg} / \mathrm{kg}$ group with restricted

Table 4. Rates of transfer of ${ }^{59} \mathrm{Fe}$ (pmol/cm per min) across intestinal segments from rats fed on magnesium-deficient and magnesium-adequate diets, measured in vitro and in vivo*

(Mean values and standard deviations)

\begin{tabular}{|c|c|c|c|c|c|c|c|}
\hline \multirow{2}{*}{$\begin{array}{l}\text { Luminal }{ }^{59} \mathrm{Fe} \\
\text { concentration }\end{array}$} & \multirow[b]{2}{*}{$n$} & \multicolumn{2}{|c|}{ Mg-deficient diet } & \multicolumn{2}{|c|}{$\mathrm{Mg}$-adequate diet } & \multicolumn{2}{|c|}{$\begin{array}{c}\mathrm{Mg} \text {-adequate diet } \\
+10 \text { mmol } \mathrm{Mg} / \mathrm{lin} \\
\text { perfusate }\end{array}$} \\
\hline & & Mean & SD & Mean & SD & Mean & SD \\
\hline \multicolumn{8}{|l|}{ In vitro transfer } \\
\hline $10 \mu \mathrm{mol} / 1$ & 5 & 5.0 & 2.5 & 5.4 & 2.9 & 6.5 & $2 \cdot 8$ \\
\hline $100 \mu \mathrm{mol} / 1$ & 5 & 37.5 & $12 \cdot 5$ & $38 \cdot 8$ & 17.0 & $42 \cdot 1$ & 11.9 \\
\hline \multicolumn{8}{|l|}{ In vivo transfer } \\
\hline $1 \mathrm{mmol} / 1$ & 3 & 118 & 17 & 121 & 61 & & \\
\hline
\end{tabular}

*For details of procedures, see pp. 477-479. 


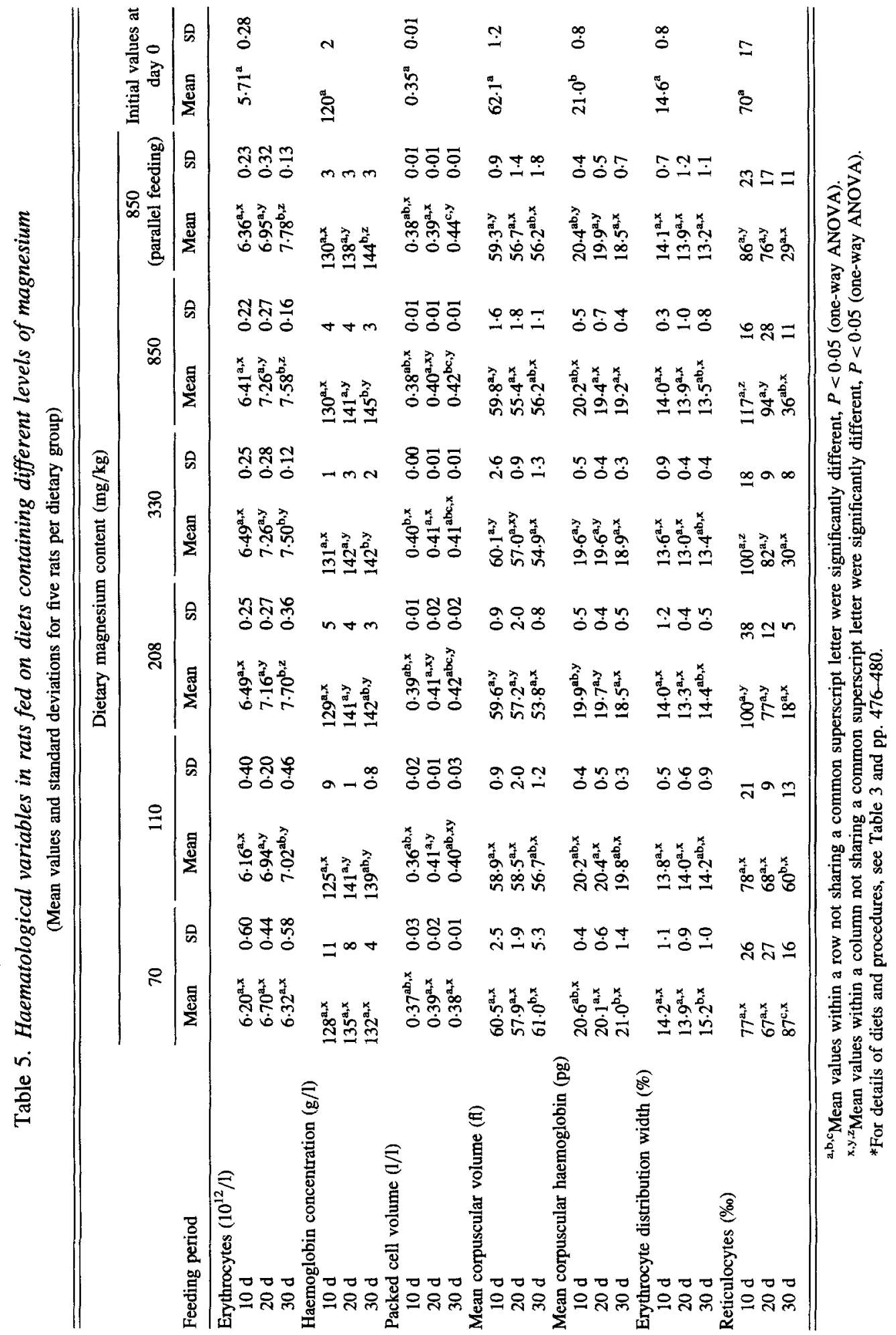


Table 6. Magnesium content of the erythrocytes of rats fed on diets containing different levels of magnesium for $30 \mathrm{~d}$

(Mean values and standard deviations for five rats per dietary group)

\begin{tabular}{|c|c|c|}
\hline \multirow[b]{2}{*}{ Dietary magnesium content $(\mathrm{mg} / \mathrm{kg})$} & \multicolumn{2}{|c|}{$\begin{array}{l}\text { Erythrocyte magnesium } \\
(\mu \mathrm{mol} / \mathrm{g} \text { dry wt) }\end{array}$} \\
\hline & Mean & SD \\
\hline 70 & $2.7^{\mathrm{a}}$ & 0.3 \\
\hline 110 & $3 \cdot 1^{\mathrm{a}}$ & 0.9 \\
\hline 208 & $5.8^{b}$ & 0.5 \\
\hline 330 & $6 \cdot 6^{6 \mathrm{c}}$ & 0.5 \\
\hline 850 & $7 \cdot 1^{c}$ & 0.4 \\
\hline 850 (parallel feeding) & $7.0^{\mathrm{c}}$ & 0.3 \\
\hline
\end{tabular}

${ }^{\mathrm{a}, \mathrm{b}, \mathrm{c}}$ Mean values not sharing a common superscript letter were significantly different, $P<0.05$ (ANOVA).

feeding after $10 \mathrm{~d}$ which were probably caused by insufficient Fe supply during fast growth due to reduced food intake (see Table 7). The Mg content was determined in erythrocytes after $30 \mathrm{~d}$. It was significantly reduced in groups with less than $330 \mathrm{mg} \mathrm{Mg} / \mathrm{kg}$ in the diet. In the $70 \mathrm{mg} \mathrm{Mg} / \mathrm{kg}$ group the values were reduced to about $40 \%$ of those found in the $850 \mathrm{mg} \mathrm{Mg} / \mathrm{kg}$ group that was fed in parallel (Table 6).

Total plasma bilirubin and plasma LDH concentrations indicated a significantly increased degree of haemolysis in the $70 \mathrm{mg} \mathrm{Mg} / \mathrm{kg}$ group after 20 and $30 \mathrm{~d}$ (Table 5). After $30 \mathrm{~d}$ the number of reticulocytes increased significantly in severe $\mathrm{Mg}$ deficiency (Table 7). Significant increases in the hepatic and splenic tissue Fe content in the $70 \mathrm{mg} \mathrm{Mg} / \mathrm{kg}$ group were observed no earlier than after 20 and $30 \mathrm{~d}$ respectively, i.e. they appeared in parallel to haemolysis (Table 7).

Urea and creatinine showed no significant differences between the $70 \mathrm{mg} \mathrm{Mg} / \mathrm{kg}$ group and the $850 \mathrm{mg} \mathrm{Mg} / \mathrm{kg}$ group after $30 \mathrm{~d}$ (urea: 294 (SD 58) v. 244 (SD 63) mg/l; creatinine: 5.4 (SD 3) v. 5.0 (SD 3) $\mathrm{mg} / \mathrm{l} ; n$ 5) (Student's $t$ test; $P>0.05$ ).

\section{Correlation between released haemoglobin iron and increased tissue iron content (Expt 1)}

The released haemoglobin Fe quantities and the increases of the tissues Fe content in spleen and liver in the $70 \mathrm{mg} \mathrm{Mg} / \mathrm{kg}$ group were estimated by comparison with the $850 \mathrm{mg} \mathrm{Mg} / \mathrm{kg}$ controls that were fed in parallel to the food consumption in the most $\mathrm{Mg}$ deficient group. The body weights of corresponding animals in each group at the beginning of the experiment were similar (Table 2). The animals in both groups ate the same quantity of food with the same Fe content. Intestinal $\mathrm{Fe}$ absorption was not significantly different between the two groups (Table 4) and Fe losses in rats are negligible (Kreuzer \& Kirchgessner, 1991). Therefore, for the comparisons made in this paragraph corresponding animals in the two groups were assumed to have the same total body Fe content. Haemoglobin-bound Fe was calculated from the individual haemoglobin concentration, assuming a blood volume of $6.7 \%$ of the body weight (Whittaker et al. 1984) and an $\mathrm{Fe}$ content of $3.4 \mathrm{mg} / \mathrm{g}$ haemoglobin. The difference in the estimated haemoglobin-bound $\mathrm{Fe}$ for each pair of animals from both groups was regarded as haemoglobin Fe released by haemolysis. The differences between the Fe content in the liver and spleen for each pair were correlated with the corresponding value estimated for liberated haemoglobin $\mathrm{Fe}$. As no significant haemolysis or tissue $\mathrm{Fe}$ accumulation was seen after $10 \mathrm{~d}$, only the values 


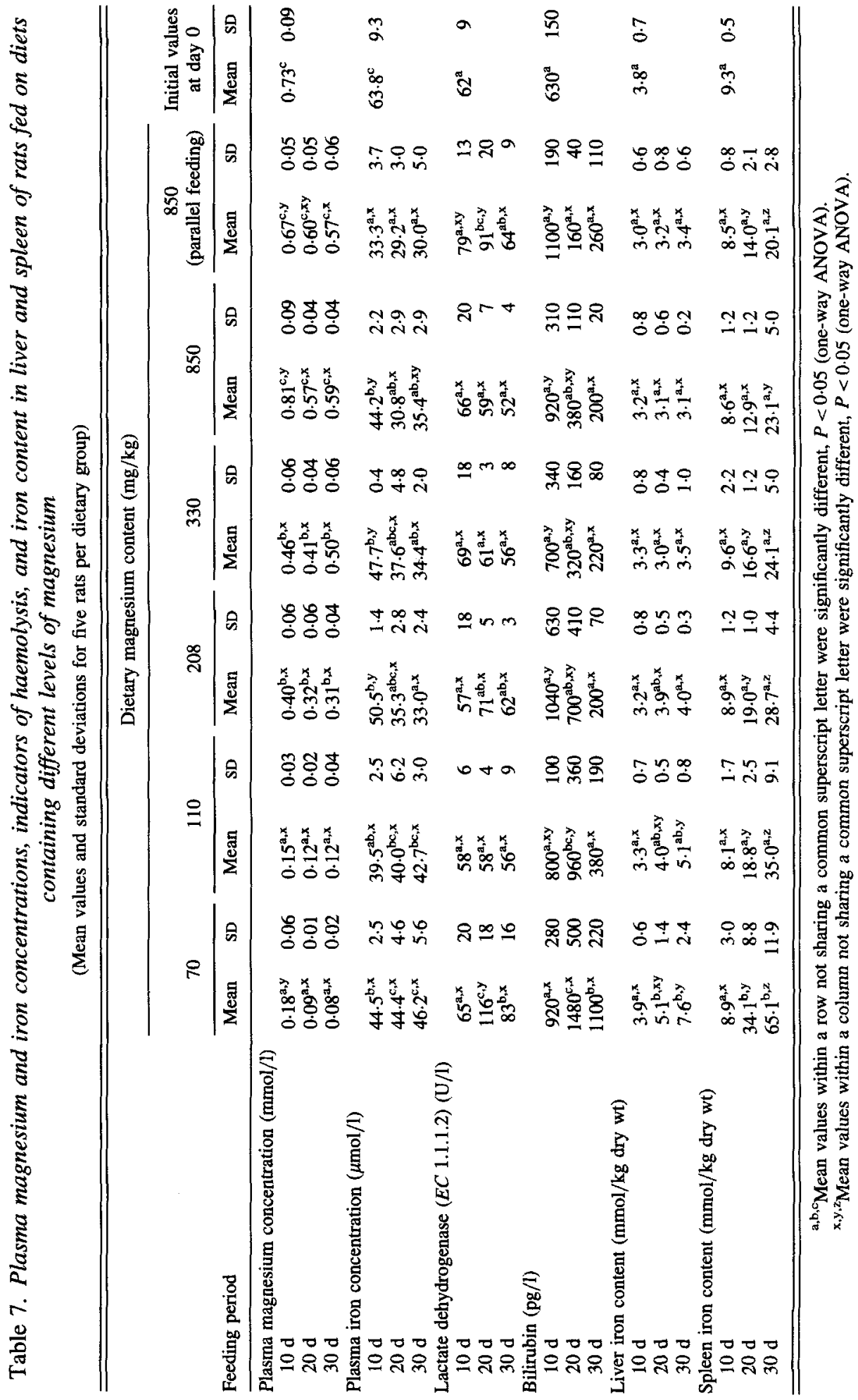


after 20 and $30 \mathrm{~d}$ were used for the correlation. The correlation coefficients for these organs were 0.83 and $0.82(P<0.01$; results not shown).

\section{Histological findings (Expt 1)}

Light microscopy revealed no morphological alterations of the hepatic parenchyma. $\mathrm{Fe}$ storage in the liver was restricted to the Kupffer cells. Kupffer-cell siderosis was found almost exclusively in the $70 \mathrm{mg} \mathrm{Mg} / \mathrm{kg}$ and $110 \mathrm{mg} \mathrm{Mg} / \mathrm{kg}$ groups and occurred in parallel with marked siderosis of macrophages in the spleen (Table 8). Due to the fast growth rates the bone marrow showed high erythropoietic activity in all groups accompanied by negative Perls' blue reaction, indicating a lack of stainable Fe in macrophages from the bone marrow. Although extramedullary haematopoiesis was observed in the spleen in all animals, the $70 \mathrm{mg} \mathrm{Mg} / \mathrm{kg}$ group showed the highest erythropoietic activity (Table 8). In the young control animals which were slaughtered at the beginning of the feeding period high extramedullary erythropoiesis went along with a lack of siderosis in the spleen.

Renal tubular calcifications as a characteristic lesion in $\mathrm{Mg}$ deficiency were found in almost all animals of the 70,110 , and $208 \mathrm{mg} \mathrm{Mg} / \mathrm{kg}$ groups. Only one in five rats in the 330 and two in five animals in the $850 \mathrm{mg} \mathrm{Mg} / \mathrm{kg}$ groups showed intratubular concretions (Table 8). The extent of these changes correlated with the extent of $\mathrm{Mg}$ deficiency and was observed even in the $850 \mathrm{mg} \mathrm{Mg} / \mathrm{kg}$ ad libitum group, though not, however, in the $850 \mathrm{mg} \mathrm{Mg} / \mathrm{kg}$ group with restricted feeding.

\section{DISCUSSION}

The quantitative correlation and the simultaneous appearance of haemolysis and siderosis hint that an incomplete erythropoietic utilization and, hence, a disturbed redistribution of $\mathrm{Fe}$ from haemolysed erythrocytes may be the cause of tissue $\mathrm{Fe}$ accumulation in $\mathrm{Mg}$ deficiency. The authors are well aware that correlation cannot prove a causal relationship. However, it seems worthwhile to draft a hypothesis for the mechanisms leading to tissue siderosis in $\mathrm{Mg}$ deficiency based on the presented findings and on the available data from the literature.

There are three possible ways in which $\mathrm{Fe}$ can accumulate in the body: first, a reduction in $\mathrm{Fe}$ excretion can be assumed to lead to increased body $\mathrm{Fe}$ retention. This possibility can be discounted, however. As daily $\mathrm{Fe}$ losses in mammals make up less than $0.1 \%$ of total body Fe (Lynch, 1984), a further reduction cannot account for the substantial increases in tissue $\mathrm{Fe}$ that were found after 20 and $30 \mathrm{~d}$. Second, the increased tissue $\mathrm{Fe}$ load in $\mathrm{Mg}$ deficiency may be due to increased intestinal Fe absorption or, third, to an altered distribution of total body Fe.

\section{Intestinal iron absorption}

The state of Fe repletion is geared to the demand by adaptation of intestinal Fe absorption (McCance \& Widdowson, 1937). An increased intestinal absorption capacity for Fe serves to normalize the tissue $\mathrm{Fe}$ content in Fe deficiency and is assumed to cause Fe overload in hereditary haemochromatosis (Lambard et al. 1990). Thus, increased Fe absorption is a possible cause of $\mathrm{Fe}$ overload in the tissue. Intestinal $\mathrm{Fe}$ absorption increases most markedly in Fe-deficient segments from the proximal small intestine (Schümann et al. 1990a) which makes such segments first choice for Fe transfer experiments. In $\mathrm{Mg}$ deficiency intestinal $\mathrm{Fe}$ absorption was not significantly increased, either in vitro or in vivo, 


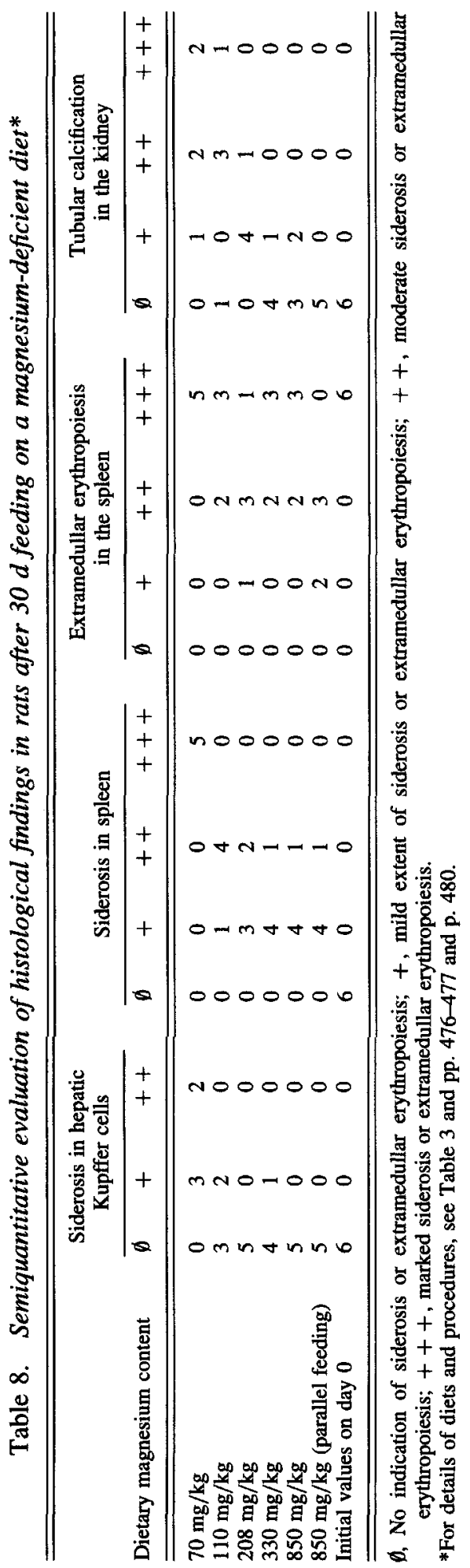


either at high or at low luminal Fe concentrations. Also, there was no reduction of intestinal

${ }^{59} \mathrm{Fe}$ mucosa-to-serosa transfer at high luminal $\mathrm{Mg}$ concentrations. The ${ }^{59} \mathrm{Fe}$ transfer rates were in the same order of magnitude as the control values determined with corresponding methods in earlier experiments (Schümann et al. 1990a). Mg had no appreciable effect on the ${ }^{59} \mathrm{Fe}^{3+}$ uptake into the mucosa of hypoxic mice while it reduced the ${ }^{59} \mathrm{Fe}^{3+}$ uptake in control mice (Raja et al. 1987). To our knowledge no information is available on the impact of high $\mathrm{Mg}$ concentrations on ${ }^{59} \mathrm{Fe}$ mucosa-to-serosa transfer. Our present results indicate that intestinal $\mathrm{Fe}$ absorption does not increase in $\mathrm{Mg}$ deficiency due to lack of inhibition by high luminal $\mathrm{Mg}$ concentrations.

\section{Redistribution of iron from haemolysed erythrocytes}

As decreased $\mathrm{Fe}$ losses and increased $\mathrm{Fe}$ absorption are ruled out as possible causes, the mechanism to be considered is a changed distribution of body Fe. In neoplastic diseases and in chronic inflammation Fe accumulates in the reticuloendothelial system (RES) which decreases the plasma Fe concentration (Bothwell et al. 1979). In severe $\mathrm{Mg}$ deficiency (70 and $110 \mathrm{mg} \mathrm{Mg} / \mathrm{kg}$ after 20 and $30 \mathrm{~d}$ ), however, the plasma Fe conCentration was increased. Thus, tissue $\mathrm{Fe}$ accumulation in $\mathrm{Mg}$ deficiency cannot be caused by this mechanism. Also, anaemia in $\mathrm{Mg}$ deficiency was neither microcytic nor hypochromic which shows that it was not due to decreased availability of Fe. This is supported by the unchanged plasma transferrin concentrations in $\mathrm{Mg}$ deficiency indicating ample availability of $\mathrm{Fe}$ in the livers.

In normal states of Fe repletion approximately 60-70\% of body $\mathrm{Fe}$ is contained in haemoglobin while another $20 \%$ is stored in the tissue (Lynch, 1984). These values show that the only compartment sufficiently large to serve as a source for substantial increases of tissue Fe stores is the haemoglobin Fe pool. Plasma Mg was significantly decreased as early as after $10 \mathrm{~d}$. Haemolysis was retarded in comparison with this effect. Excessive amounts of haemoglobin Fe were liberated in the $70 \mathrm{mg} \mathrm{Mg} / \mathrm{kg}$ and $110 \mathrm{mg} \mathrm{Mg} / \mathrm{kg}$ groups no earlier than after 20 and $30 \mathrm{~d}$ of $\mathrm{Mg}$-deficient feeding. Haemolysis developed in parallel to the tissue Fe increases in liver and spleen. These two organs were chosen because they reach the highest Fe content in Mg deficiency (Kimura \& Itokawa, 1989). The simultaneous appearance of haemolysis and tissue $\mathrm{Fe}$ accumulation suggests that the excess tissue Fe may, indeed, derive from haemolysed erythrocytes. This conclusion is supported by the high correlation of the estimated increases in tissue Fe content with the estimated Fe quantities liberated from haemolysed erythrocytes.

At the end of their life cycle erythrocytes are phagocytosed. Haemoglobin Fe is taken up by the reticuloendothelial system and is rechannelled into erythropoiesis (Bothwell et al. 1979). Thus, increased haemolysis should be compensated by increased erythropoiesis. Therefore, erythropoietic activity was quantified by reticulocyte counts and by semiquantitative evaluation of extramedullar erythopoiesis. There was no indication of insufficient erythropoiesis due to inaccessibility of $\mathrm{Fe}$ to the erythron: plasma $\mathrm{Fe}$ concentrations were high, anaemia was not microcytic or hypochromic and plasma transferrin concentrations were not increased. Fast growth increases the demand for erythrocytes which, in turn, leads to an increased erythropoietic activity. Indeed, high reticulocyte counts were found during the animal's fast growth periods, i.e. in the controls on day 0 as well as after 10 and $20 \mathrm{~d}$. Correspondingly, reticulocytosis was most marked in the $\mathrm{Mg}$-adequate controls $(850 \mathrm{mg} \mathrm{Mg} / \mathrm{kg}$ ) which grew the fastest. The expected stimulation of erythropoiesis after $20 \mathrm{~d}$ was entirely obscured by the growth effect, indicating that a reticulocyte count of $80-120 \%$ represents a maximum of erythropoietic 
activity that cannot be surpassed under these conditions. After $30 \mathrm{~d}$ reticulocytosis had significantly decreased in the $\mathrm{Mg}$-adequate controls and this was accompanied by a reduced erythrocyte distribution width. However, it remained high in the $70 \mathrm{mg} \mathrm{Mg} / \mathrm{kg}$ and $110 \mathrm{mg} \mathrm{Mg} / \mathrm{kg}$ groups which showed marked haemolysis. In the $70 \mathrm{mg} \mathrm{Mg} / \mathrm{kg}$ group reticulocytosis reached the same order of magnitude as during fast growth which seems to be the maximum that can be reached by this type of stimulus. These findings are supported by the semiquantitative evaluation of the extramedullar erythropoiesis in the spleen which was at maximum in all control animals on day 0 as well as in the $70 \mathrm{mg} \mathrm{Mg} / \mathrm{kg}$ group after $30 \mathrm{~d}$. However, the estimation of the liberated haemoglobin Fe in the $70 \mathrm{mg} \mathrm{Mg} / \mathrm{kg}$ group shows that this level of erythropoiesis is insufficient to cope with haemolysis. The excess Fe which cannot be rechannelled into erythropoiesis is mopped up by the tissue.

\section{Histological findings}

As in other haemolytic states Fe accumulates in the cells of the hepatic and splenic RES. Besides the fact that aged erythrocytes are dissembled preferentially in the spleen the strongly developed RES in liver and spleen may explain why Fe concentrations are highest in these two organs (Kimura \& Itokawa, 1989). In the present experiments hepatic and splenic Fe was found exclusively in reticuloendothelial cells. This seems to be a very successful protection of the parenchymal cells. The lack of stainable Fe may explain why no morphological alterations were detectable in hepatocytes. Still, alanine aminotransferase ( $E C$ 2.6.1.2) and aspartate aminotransferase ( $E C$ 2.6.1.1), both of which are specific indicators of a parenchymal liver damage, were observed to increase by approximately $30 \%$ in severe $\mathrm{Mg}$ deficiency. These findings from the same experiments have been published elsewhere (Vormann et al. 1995). Although these increases were significant they were small compared with those of the hepatic malondialdehyde content which indicated a tripling of lipid peroxidation (Vormann et al. 1995). The diversion of $\mathrm{Fe}$ away from the hepatocytes into the Kupffer cells may explain the discrepancy between the increased lipid peroxidation and the lack of corresponding indicators for parenchymal damage.

Tubular calcifications in the kidney of $\mathrm{Mg}$-deficient rats have been described earlier (Rob et al. 1993). Although $500 \mathrm{mg} \mathrm{Mg} / \mathrm{kg}$ was described to be an adequate $\mathrm{Mg}$ supply for rats (Cook, 1973) the observation of tubular calcification in the kidney shows that this is not the case during fast growth. This interpretation is underlined by the lack of calcification in the slower growing $850 \mathrm{mg} \mathrm{Mg} / \mathrm{kg}$ group with restricted feeding. Concentrations of urea and creatinine in the plasma, however, were not significantly increased. Thus, uraemia as a cause of haemolysis can be excluded.

\section{Speculation on possible causes of haemolysis in magnesium deficiency}

The $\mathrm{Mg}$ content of erythrocytes corresponds to the plasma $\mathrm{Mg}$ at the time of their synthesis (Günther \& Vormann, 1985). The life span of rat erythrocytes is approximately $60 \mathrm{~d}$. If haemolysis is assumed to be related to the erythrocyte's $\mathrm{Mg}$ content this explains the retardation of haemolysis compared with the decreases in plasma $\mathrm{Mg}$ concentrations.

From the results presented here we cannot derive any conclusions regarding the molecular mechanisms which mediate an increase in haemolysis. However, possible explanations can be derived from the literature. For example, the shortened erythrocyte survival is accompanied by decreased erythrocyte contents of pyrophosphatase ( $E C$ 3.6.1.9) (Elin et al. 1971) and by a decreased glucose utilization in erythrocytes leading to decreased ATP and 2,3-diphosphoglycerate concentrations (Oken et al. 1971). Recently, binding of free Fe to divalent cation binding sites in the erythrocyte (band 3 protein) has 
been shown to induce formation of a senescent antigen which may induce destruction of the erythrocyte by subsequent binding of immunoglobulin G (Signorini et al. 1995). $\mathrm{Mg}$ is the main divalent cation within the erythrocyte that may compete with $\mathrm{Fe}$ for the band 3 binding sites. In the present experiments the $\mathrm{Mg}$ content in the erythrocytes was reduced to less than half of the control value after $30 \mathrm{~d}$. This changes the ratio between free intracellular $\mathrm{Fe}$ and $\mathrm{Mg}$ and should induce increased $\mathrm{Fe}$ binding to the band 3 protein and increased formation of the senescent antigen. In consequence, erythrocyte survival should be shortened in $\mathrm{Mg}$ deficiency and haemolysis should increase, which is what happened in the present study. It may even explain the retardation of haemolysis as compared with decreases in plasma $\mathrm{Mg}$ concentrations.

In summary, the following hypothesis may explain the increased tissue $\mathrm{Fe}$ accumulation in $\mathrm{Mg}$ deficiency: severe $\mathrm{Mg}$ deficiency leads to formation of $\mathrm{Mg}$-deficient erythrocytes with a decreased survival time resulting in haemolysis. The released $\mathrm{Fe}$ that exceeds the erythropoietic capacity is mopped up by the tissue, leading to haemosiderosis.

The increased tissue Fe content in $\mathrm{Mg}$ deficiency leads to increased lipid peroxidation (Günther et al. 1992) without increased dietary Fe supply, which may be of interest in the ongoing discussion on the potential harm of high oral Fe supply. However, haemolysis, which seems to be a prerequisite to increase the tissue Fe content in $\mathrm{Mg}$ deficiency occurs only at plasma $\mathrm{Mg}$ concentrations below $0.25 \mathrm{mmol} / 1$ (Vormann et al. 1995). Such values are rarely reached in humans except under medication e.g. with ciclosporine (Rob et al. 1993) or diuretics. Provided that there are no dramatic differences between species, therefore, increased tissue $\mathrm{Fe}$ accumulation and the described pathophysiological consequences should rarely occur in humans. This may be different, however, when $\mathrm{Mg}$ deficiency is accompanied by other factors that stimulate haemolysis or lipid peroxidation.

We thank $\mathrm{H}$. Janser for technical assistance with the animal experiments and Frau von Werder and her team for the determination of haematological and plasma variables.

\section{REFERENCES}

Bothwell, T. H., Charlton, R. W., Cook, J. D. \& Finch, C. A. (1979). Iron Metabolism in Man, pp. $327-352$. Oxford, London, Edinburgh, Melbourne: Blackwell Scientific Publications.

Classen, H. G., Speich, M., Schimatschek, H. F. \& Rattanatayarom, W. (1994). Functional role of magnesium in vivo. In Magnesium, 1993, pp. 13-30 [S. Golf, D. Dralle and L. Vecchient, editors]. London: John Libbey.

Cook, D.A. (1973). Availability of magnesium: balance studies in rats with various inorganic salts. Journal of Nutrition 103, 1365-1370.

Crichton, R. R. (1991). Inorganic Biochemistry of Iron Metabolism. New York: Ellis Horwood.

Elin, R. J., Armstrong, W. D. \& Singer, L. (1971). Enzyme, adenosine triphosphate, and blood cellular changes in magnesium deficient and control rats. Proceedings of the Society for Experimental Biology and Medicine 137, 635-640.

Fisher, R. B. \& Parsons, D. S. (1949). A preparation of surviving rat small intestine for the study of absorption. Journal of Physiology 110, 36-46.

Günther, T. (1981). Biochemistry and pathobiochemistry of magnesium. Magnesium Bulletin 3, 91-101.

Günther, T. \& Vormann, J. (1985). Removal and reuptake of intracellular magnesium. Magnesium Bulletin 7 , 66-69.

Günther, T., Vormann, J. Höllriegl, V., Disch, G. \& Classen, H.-G. (1992). Role of lipid peroxidation and vitamin $\mathrm{E}$ in magnesium deficiency. Magnesium Bulletin 14, 57-66.

Kimura, M. \& Itokawa, Y. (1989). Ineffective utilization of iron and minerals in magnesium deficient rats. In Magnesium in Health and Disease, pp. 95-102 [Y.I. Itokawa and J. Durlach, editors]. London: John Libbey Ltd.

Kreuzer, M. \& Kirchgessner, M. (1991). Endogenous iron excretion. A quantitative means to control iron metabolism. Biological Trace Element Research 29, 77-92.

Lambard, M., Bomford, A.B., Polson, R. J., Bellingham, A. J. \& Williams, R. (1990). Differential expression of transferrin receptor in duodenal mucosa in iron overload. Gastroenterology 98, 976-984. 
Lynch, S. R. (1984). Iron. In Absorption of Mineral Nutrients, pp. 89-124 [N. W. Solomons and I. H. Rosenberg, editors]. New York: Alan R. Liss Inc.

McCance, R. A. \& Widdowson, E. M. (1937). Absorption and excretion of iron. Lancet, 680-684.

Oken, M. M., Lichtman, M. A., Miller, D. R. \& Leblond, P. (1971). Spherocytic hemolytic disease during magnesium deprivation in the rat. Blood 38, 468-478.

Raja, K. B., Simpson, R. J. \& Peters, T. J. (1987). Effect of $\mathrm{Ca}^{2+}$ and $\mathrm{Mg}^{2+}$ on the uptake of $\mathrm{Fe}^{3+}$ by mouse intestinal mucosa. Biochimica et Biophysica Acta 923, 46-51.

Rob, P. M., Lebeau, A., Maas, S., Weigelt, J., Schmid, H., Mansky, T. \& Classen, H.-G. (1993). Ciclosporineinduced nephrotoxicity in rats affected by different dietary magnesium levels. Magnesium Bulletin 15, 69-75.

Schaefer, H. E. (1995). Die histologische Bearbeitungstechnik von Beckenkammbiopsien auf der Basis von Entkalkung und Paraffineinbettung unter Berücksichtigung osteologischer und hämatologischer Fragestellungen (Histological techniques for the treatment of biopsies from the pelvic crest on the basis of decalcification and imbedding with regard to osteological and haematological questions). Pathologe 16, 11-27.

Schümann, K., Elsenhans, B., Ehtechami, C. \& Forth, W. (1990a). Rat intestinal iron transfer capacity and the longitudinal distribution of its adaptation to iron deficiency. Digestion 46, 35-45.

Schümann, K., Elsenhans, B., Ehtechami, C. \& Forth, W. (1990b). Increased intestinal iron absorption in rats with normal hepatic iron stores. Kinetic aspects of the adaptive response to parenteral iron repletion. Biochimica et Biophysica Acta 1033, 277-281.

Schümann, K., Osterloh, K. \& Forth, W. (1986). Independence of in vitro iron absorption from mucosal transferrin content in rat jejunal and ileal segments. Blut 53, 391-400.

Searle, J., Kerr, J. F. R., Halliday, J. W. \& Powell, L. W. (1994). Iron storage diseases. In Pathology of the Liver, 3rd ed., pp. 219-241 [R. N. M. MacSween, P. P. Anthony, P. J. Scheuef, A. D. Burt and B. C. Portman, editors]. Edinburgh, London, Madrid, Melbourne, New York, Tokyo: Churchill Livingstone.

Signorini, C., Ferali, M., Ciccoli, L., Sugherini, L., Magnani, A. \& Comporti, M. (1995). Iron release, membrane protein oxidation and erythrocyte ageing. FEBS Letters 362, 165-170.

Vormann, J., Günther, T., Höllriegl, V. \& Schümann, K. (1995). Effect of various degree and duration of magnesium deficiency on lipid peroxidation and mineral metabolism in rats. Journal of Nutritional Biochemistry 6, 681-688.

Whittaker, P., Mahoney, A. W. \& Hedricks, D. G. (1984). Effect of iron-deficiency anaemia on per cent blood volume in growing rats. Journal of Nutrition 114, 1137-1142.

Woods, K. L. \& Fletcher, S. (1994). Long-term outcome after intravenous magnesium sulphate in suspected acute myocardial infarction: the second Leicester intravenous magnesium intervention trial (LIMIT-2). Lancet 343, 816-819. 